DOI 10.7764/rcia.v45i3.1856

\title{
RESEARCH PAPER \\ Growth responses after a future crop tree thinning and a thinning from below in a second-growth Nothofagus pumilio forest in Tierra del Fuego, Chile
}

\author{
Gustavo E. Cruz, Fernando A. Rodriguez, Patricio A. Tapia, and Horacio E. \\ Bown \\ Universidad de Chile, Facultad de Ciencias Forestales y de la Conservación de la Naturaleza. Santa Rosa \\ 11315, La Pintana, Casilla 9206, Santiago, Chile.
}

\begin{abstract}
G.E. Cruz, F.A. Rodríguez, P.A. Tapia, and H.E. Bown. 2018. Growth responses after a future crop tree thinning and a thinning from below in a second-growth Nothofagus pumilio forest in Tierra del Fuego, Chile. Cien. Inv. Agr. 45(3): 263-276. Nothofagus pumilio (lenga) is the most important native species for timber production in southern Patagonia both in Chile and Argentina. Thinning application to second-growth N. pumilio forests has been limited in Patagonia, probably because of the long time necessary for the investment to be recovered. In addition, experimental trials have focused mostly on thinnings from below, leaving a high residual stand density, which has led to a modest growth response. Using measurements (1995-2014) obtained from a thinning trial carried out in a second-growth $N$. pumilio forest located in Tierra del Fuego (Chile), the objective of this case study was to analyze whether selective thinnings with future crop trees (in the sense of Z-Bäumen thinning) promote greater growth responses than those from a thinning from below. In addition, we explored the associations between climatic factors and age on $N$. pumilio tree growth. Trial treatments comprised a control, a thinning from below and a future crop tree thinning. The growth response after a future crop tree thinning was greater and lasted for a longer period (10 yrs) than did the thinning from below (4 yrs). The tree basal area and diameter at breast height (dbh) growth increased with dbh and annual absolute minimum temperature and decreased with age for the unthinned treatment during the period from 1977-2014 ( 70-110 yrs old). Our results suggest that the future crop thinning might be a better alternative than the thinning from below for secondary N. pumilio forests in Patagonia due to the greater growth response while being a less intensive silvicultural method.
\end{abstract}

Key words: Climatic factors, lenga, Patagonia, thinning treatments

\section{Introduction}

Nothofagus pumilio (Poepp. et Endl.) Krasser (lenga) is the most important native species for timber production in southern Patagonia both in

Received Sep 05, 2017. Accepted Oct 24, 2018. Corresponding author: gcruzm@gmail.com
Chile and Argentina. In Chile, $N$. pumilio forest covers an area of approximately 3.6 million ha, concentrated mainly in the regions of Aysén and Magallanes. In Magallanes, primary N. pumilio forests cover approximately 735 thousand ha, while second-growth forests cover approximately 131 thousand ha, which have originated from adult forests partially or totally destroyed by old fires 
or unregulated logging since the colonization period in the $19^{\text {th }}$ century. In southern Patagonia and Tierra del Fuego, approximately 200-300 thousand ha were transformed into pasture (Lara and Cruz, 1987, Cruz and Schmidt, 2007). In many cases, the pastures were abandoned, and a secondary forest was re-established. In Tierra del Fuego, second-growth forests cover an area of approximately 61 thousand ha (CONAF, 2011).

Thinnings and improvement cuttings in young $N$. pumilio forests have only been applied experimentally or in small extensions in Patagonia (Uriarte y Grosse, 1991, Chávez, 2002, Schmidt et al., 2003, Contreras, 2004, Maulen, 2015), despite the existence of state subsidies for their application (Neira y Rivas, 2013). Thinnings in secondary forest stands would reduce the time required to yield larger and better-priced logs, concentrate growth on selected trees, and harvest an intermediate yield that would otherwise be lost by natural mortality.

In Central European forestry, a variation of a selective thinning (Schädelin, 1942), commonly referred to as crop tree thinning in the sense of the German term Z-Bäumen (Abetz, 1979) or the American term free thinning (Helms, 1998, Nyland, 2016), has been frequently used. These healthy and vigorous future crop trees are promoted in the long term by removing a defined number of competitors (Pretzsch, 2009). By future crop tree thinning (FCT henceforth), we mean the selective thinning in young stands (pole timber stage), where final crop trees are chosen and permanently marked and kept until reaching a desired target diameter at breast height (dbh). Trees other than future crop trees are kept alive and may represent a fair proportion of the total basal area.

There are several reasons for the lack of interest in applying thinnings in young $N$. pumilio forests in the Magallanes Region in Chile. Thinning trials in the region have dealt mostly with thinning from below, testing different intensities in spacing and basal area. The current thinning from below scheme considers leaving a residual stand with a high density of young trees, which leads to high intraspecific competition resulting in a modest growth response and low-quality timber in the future (Cruz, 1997). In addition, a thinning from below would generally involve felling the smalldiameter trees, which would be generally left in the forest as a result of the low demand for small logs and the high logging and transport costs.

In contrast, selective thinnings based on a small number of future crop trees (100-300) prevent an excessive harvest of low-quality trees, thus reducing the costs of the intervention in line with the government subsidies available (Cruz, 2017). Additionally, wind damage and windthrow are common in N. pumilio forests (Rebertus et al., 1997; Peri et al., 2002), affecting stand stability and threatening the success of silvicultural operations (Peri et al., 2002). Therefore, low-intensity thinning practices that eliminate only the effective competitors (such as FCT thinning) could prevent large-scale windthrow and reduce the negative visual impact of managed forests (Peri et al., 2013). FCT thinning may also lead to rapid growth and the production of quality wood, which would better contribute to carbon sequestration at the tree and stand level and to the long-term storage of carbon into end products. Despite the apparent advantages of future crop tree thinning over thinning from below, silvicultural trials focused on the growth responses of the former on young $N$. pumilio forests are scarce, usually covering relatively short periods of time (Contreras, 2004; Peri et al., 2013; Maulen, 2015).

To the best of our knowledge, the trial reported in this study is one of a few with a longer monitoring time (19 yrs), allowing us to describe the medium-term growth responses of a control, a thinning from below and an FCT thinning treatments. We analyzed whether selective thinnings with future crop trees could bring about greater growth responses than those from a thinning from below for second-growth $N$. pumilio forests in Tierra del Fuego. In addition, we explored the 
associations between climatic factors and age on Nothofagus pumilio stem growth in the unthinned treatment to better separate the effects of thinnings from other factors controlling the growth of $N$. pumilio forests. These results and discussion may contribute to better silvicultural decision-making for sustainable forest management.

\section{Materials and methods}

\section{Study area}

The study was conducted in a second-growth $N$. pumilio forest located in the "Cazuelas" property (534 44'08” S; 6906’46”; $160 \mathrm{~m}$ a.s.1.), owned by the company Forestal Russfin Ltda., Tierra del Fuego Island, in the Magallanes Region, Chile (Figure 1). Trials were established in a second-growth stand with two cohorts coexisting in 1995. At that time, the older, overmature cohort was approximately 250-300 yrs old, with approximately 48 trees per hectare, a basal area of $12.1 \mathrm{~m}^{2} \mathrm{ha}^{-1}$, and an average dbh of $58 \mathrm{~cm}$. The younger cohort was approximately $80-100$ yrs old, with 1,820 trees per hectare, a $56.3 \mathrm{~m}^{2}$ ha $^{-1}$ basal area, and an average dbh of $21 \mathrm{~cm}$. A future crop tree thinning (FCT) in the sense of the German term Z-Bäumen (Abetz, 1979) was carried out on $1.2 \mathrm{ha}$, a thinning from below on 2.4 ha, and 1.6 ha were left unthinned as a control. The treated areas were no more than $500 \mathrm{~m}$ apart and were similar in terms of vegetation composition and structure, soil type and topography.

The climate of the area is southern antiboreal subzone (oceanity sector $\mathrm{O}_{2}$; humid province h) (Tuhkanen, 1992), having a mean air temperature between 8.5 and $9.5^{\circ} \mathrm{C}$ for the warmest month of the yr and below zero for the coldest month. The mean annual rainfall ranges between 350 and $600 \mathrm{~mm}$, and the length of the growing season ranges between 150 and 170 days. The wind

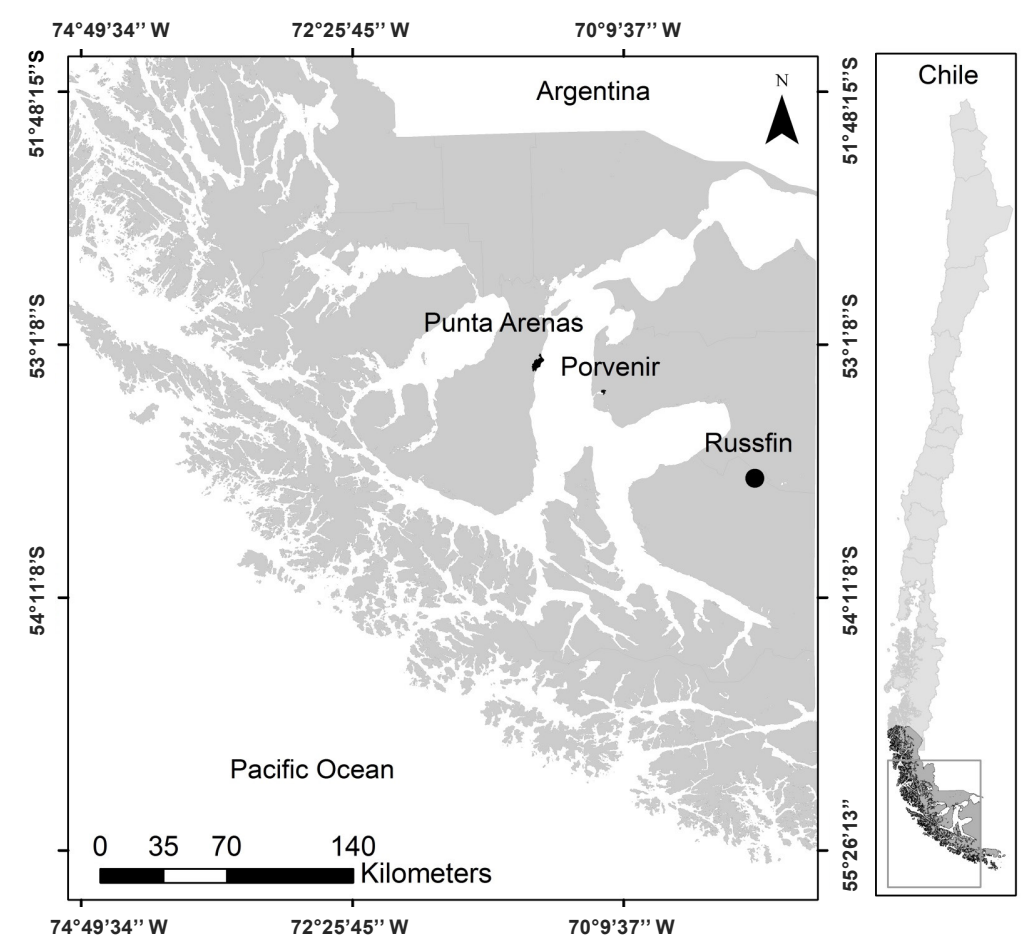

Figure 1. Study area showing the location of the secondary $N$. pumilio forests in Russfin (Cazuelas property), Tierra del Fuego, Chile. 
direction is commonly west to southwest, with speeds averages between 14 and $22 \mathrm{~km} \mathrm{~h}^{-1}$, and the maximum speeds in summer are above 100 $\mathrm{km} \mathrm{h}^{-1}$ (Tuhkanen, 1992).

The topography is rolling terrain, with slopes lower than $5 \%$. Soils have no apparent erosion and are classified within the group of humic podzols. The soils have thin to moderate depths $(<50 \mathrm{~cm})$, with sandy to loamy textures that are slightly acidic ( $\mathrm{pH}$ 5.2-5.7) and have low fertility (Caldentey, 1995). The natural vegetation is characterized by pure $N$. pumilio deciduous forest belonging to the formation of the Patagonic Andean Forest Region (Gajardo, 1994).

\section{Thinning treatments}

All thinning treatments were applied for the younger cohort (80-100 yrs old). Overmature trees (250-300 yrs old) of the older cohort were left uncut in the thinning treatment areas. The FCT thinning released 138 young trees per ha that were dominant, straight, without excessive branching, with good vitality and with the best possible spacing by eliminating one to eight competitors for each selected tree. A competitor was defined as a dominant or codominant tree with a crown that compresses or touches the crown of a future crop tree. The basal area was reduced from 68.4 to $58.7 \mathrm{~m}^{2} \mathrm{ha}^{-1}$, while the stand density was reduced from 1,868 to 1,598 trees ha $^{-1}$.

The thinning from below left the 1,320 best trees per ha (straight, without excessive branching, vigorous), maintaining an equivalent distance between them as far as possible. The basal area was reduced from 61.7 to $51.0 \mathrm{~m}^{2} \mathrm{ha}^{-1}$, while the stand density was reduced from 1,568 to 1,320 trees $\mathrm{ha}^{-1}$. The thinning intensity was defined according to the silvicultural system model proposed by Schmidt and Urzúa (1982) and Cruz and Schmidt (2007) for N. pumilio forests.
In 2002, the forest structure was characterized through a census for the FCT thinning, and through 5 randomly located $500 \mathrm{~m}^{2}$ plots for the thinning from below. Fallen trees and stumps were also measured to reconstitute the stands before and after thinning in 1995. Within the FCT thinning, trees were also classified as future crop trees, corresponding to the 138 selected trees that were directly released by the thinning in 1995; influenced trees that were indirectly released by the thinning because they were closer $(<5 \mathrm{~m})$ to the cut trees (stumps); and non-influenced trees that were apparently unaffected by the thinned trees. The average dbh, tree height $(\mathrm{h})$, tree density $(\mathrm{N})$, basal area $(\mathrm{G})$, and total overbark volume $(\mathrm{V})$ were calculated. The structure of the unthinned stand was also characterized using 5 randomly located $500 \mathrm{~m}^{2}$ plots. In 2014, the future crop thinning, the thinning from below and the control area were remeasured using 5 random plots of $500 \mathrm{~m}^{2}$ per treatment area and assessed with the same parameters as in 2002. Values of the stand density, basal area and stem volume in the younger cohort before and after thinning in 1995 and 2014 are shown in Table 1.

\section{Tree core sampling}

In 2014, increment cores were taken from tree trunks at $1.3 \mathrm{~m}$ for each treated area and the control to assess the radial growth response. All of the suitable cores were dried, mounted, sanded using sandpaper of increasingly finer grain until the growth rings were clearly visible and processed, following the standard procedures outlined by Stokes and Smiley (1996). The ring widths were recorded to the nearest $0.01 \mathrm{~mm}$ using a LINTAB measuring system and TSAP-Win TM $4.69 \mathrm{~b}$ analysis software (RINNTECH e.K., Heidelberg, Germany). The dbh increment ( $\left.\mathrm{mm} \mathrm{yr}^{-1}\right)$ both 19 yrs before and 19 yrs after the thinning were measured. A total of 250 increment wood cores were obtained: 130 from the FCT thinning treatment (70 from the future crop trees, 35 from the influenced and 25 from the non-influenced 
Table 1. Stand density (N), basal area (G) and total overbark volume (V) for the younger stratum of Nothofagus pumilio secondary forest before and after thinning treatments in 1995 and 2014.

\begin{tabular}{|c|c|c|c|c|c|c|c|c|c|}
\hline \multirow[b]{2}{*}{$\begin{array}{l}\text { Thinning } \\
\text { treatments }\end{array}$} & \multicolumn{3}{|c|}{$\begin{array}{c}\mathrm{N} \\
\left(\text { trees ha }^{-1}\right)\end{array}$} & \multicolumn{3}{|c|}{$\begin{array}{c}\mathrm{G} \\
\left(\mathrm{m}^{2} \mathrm{ha}^{-1}\right)\end{array}$} & \multicolumn{3}{|c|}{$\begin{array}{c}\mathrm{V} \\
\left(\mathrm{m}^{3} \mathrm{ha}^{-1}\right)\end{array}$} \\
\hline & $\begin{array}{c}\text { Stand before } \\
\text { thinning in } \\
1995\end{array}$ & $\begin{array}{c}\text { Stand after } \\
\text { thinning in } \\
1995\end{array}$ & $\begin{array}{c}\text { Stand after } \\
\text { thinning in } \\
2014\end{array}$ & $\begin{array}{c}\text { Stand } \\
\text { before } \\
\text { thinning in } \\
1995\end{array}$ & $\begin{array}{c}\text { Stand after } \\
\text { thinning in } \\
1995\end{array}$ & $\begin{array}{c}\text { Stand after } \\
\text { thinning in } \\
2014\end{array}$ & $\begin{array}{c}\text { Stand before } \\
\text { thinning in } \\
1995\end{array}$ & $\begin{array}{c}\text { Stand after } \\
\text { thinning in } \\
1995\end{array}$ & $\begin{array}{c}\text { Stand after } \\
\text { thinning in } \\
2014\end{array}$ \\
\hline $\begin{array}{l}\text { Future crop } \\
\text { tree thinning }\end{array}$ & 1,868 & 1,598 & 1,140 & 68.4 & 58.7 & 61.0 & 554 & 475 & 513 \\
\hline $\begin{array}{l}\text { Future crop } \\
\text { trees }\end{array}$ & & 138 & 135 & & 5.7 & 9.6 & & 45 & 81 \\
\hline $\begin{array}{l}\text { Influenced and } \\
\text { Non- } \\
\text { influence trees }\end{array}$ & & 1,460 & 1,005 & & 53.0 & 51.4 & & 430 & 432 \\
\hline $\begin{array}{l}\text { Thinning from } \\
\text { below }\end{array}$ & 1,568 & 1,320 & 1,048 & 61.0 & 51.0 & 61.7 & 503 & 432 & 520 \\
\hline Control & 1,379 & 1,379 & 1,110 & 65.5 & 65.5 & 63.6 & 562 & 562 & 539 \\
\hline
\end{tabular}

trees), 60 from the residual trees in the thinning from below treatment, and 60 from the control treatment. The cored trees were evenly distributed across dbh classes for each category of trees, i.e., future crop, influenced and non-influenced trees from the FCT treatment, the remaining trees from the thinning from below and the control trees.

\section{Climatic influences on diameter growth}

To test the association between climatic variables and annual dbh growth, we compiled the data from those weather stations with the longest and most complete instrumental temperature and precipitation records within the study area (data downloaded from explorador.cr2.cl) for the common interval, 1975-2017. This included records for the Russfin $\left(53.75^{\circ} \mathrm{S}, 69.18^{\circ} \mathrm{W}\right.$, and $225 \mathrm{~m}$ altitude) and Punta Arenas weather stations $\left(53.12^{\circ} \mathrm{S}, 70.8^{\circ} \mathrm{W}\right.$, and $5 \mathrm{~m}$ altitude). To complete the missing records, we fitted linear regression models for the daily minimum temperature, maximum temperature and precipitation for the intervals where these variables were available for both stations and applied the model fittings to the incomplete series at the Russfin station using the records from the Punta Arenas station. Consequently, correlations between the dbh increment and the climate data were calculated for trees within the unthinned control treatment over 38 yrs (from 1977 to 2014). We calculated the Pearson correlation between the $\mathrm{dbh}$ increments and the total annual precipitation, mean monthly maximum temperature, absolute maximum temperature, mean minimum monthly temperature and absolute minimum temperature for the yr, growing season (September to April) and leafless season (May to August) and considered whether the variables lagged from the previous yr.

All statistical analyses were performed using R (R Core Team, 2013). Descriptive statistics were used to compare stand-level values. At the tree level (cores), we used linear mixed models to test the relationship between the current annual increment in dbh and the tree basal area against the tree state variables (e.g., dbh and age) and environmental variables (annual air temperatures and annual rainfall). Trees were considered a random effect. P-values were obtained by likelihood ratio tests of the full model with and without the fixed factor. 


\section{Results}

\section{Overall effect of thinnings}

The FCT thinning performed in 1995 promoted the growth of the 138 most vigorous and highquality trees selected per hectare by eliminating competition around them (an average of 1.96 competitors were cut around each future crop tree), representing $14.2 \%$ of the stem basal area of the original stand (Table 1). The thinning from below removed predominantly the dominated trees, representing $16.4 \%$ of the stem basal area of the original stand.

After the thinning treatments were applied during the summer of 1994/1995, from 1995 to 2014, the stand density within the FCT thinning decreased as a consequence of natural mortality by $28.7 \%$ (from 1,598 trees ha-1 in 1995 after thinning to 1,140 trees $a^{-1}$ in 2014), although mortality was almost exclusively confined to the influenced and non-influenced trees ( $28.5 \%$ pooled together). The stand density within the thinning from below treatment decreased by $20.6 \%$ (from 1,320 trees ha ${ }^{-1}$ in 1995 to 1,048 trees ha $^{-1}$ in 2014) due to mortality (Table 1). This showed that competition-induced mortality occurred at a mean rate of 14.3 trees $\mathrm{ha}^{-1} \mathrm{yr}^{-1}$, affecting primarily the codominant and intermediate trees of the stand. The tree density for the unthinned stand decreased by $19.5 \%$ (from 1,379 trees ha $^{-1}$ in 1995 to 1,110 trees ha- ${ }^{-1}$ in 2014), similar to the mortality rate of the thinning from below treatment (Table 1).

After the thinning treatments were applied during the summer of 1994/1995, between 1995 and 2014, the basal area increment in the selective thinning treatment exhibited a slight increase (3.9\%) that was concentrated mainly on the future crop trees (68.4\%). The basal area of influenced and noninfluenced trees decreased by $3.0 \%$, which was attributed to the mortality that occurred during that period. The values of the mean quadratic diameter $\left(D_{\mathrm{g}}\right)$ of the future crop trees increased by $31.8 \%$ (from $17.9 \mathrm{~cm}$ in 1995 to $23.6 \mathrm{~cm}$ in 2014), with almost null mortality. The basal area in the thinning from below treatment increased by $21.0 \%$ (from $51.0 \mathrm{~m}^{2} \mathrm{ha}^{-1}$ in 1995 to $61.7 \mathrm{~m}^{2} \mathrm{ha}^{-1}$ in 2014), distributing this growth in the basal area to trees of different sizes, social classes and stem qualities. Consequently, the mean quadratic diameter $\left(D_{\mathrm{g}}\right)$ of the stand increased 22.9\% (from $17.4 \mathrm{~cm}$ in 1995 to $21.4 \mathrm{~cm}$ in 2014) during the same period. The basal area of the unthinned stand decreased by $2.9 \%$ due to mortality, while the mean quadratic diameter $\left(D_{\mathrm{g}}\right)$ increased by $9.9 \%$ (from $19.2 \mathrm{~cm}$ in 1995 to $21.1 \mathrm{~cm}$ in 2014) during the same period.

The total overbark volume (V) of the FCT-thinning treatment increased by only $8.0 \%$ (from 475 in 1995 to $513 \mathrm{~m}^{3} \mathrm{ha}^{-1}$ in 2014), with an average of $2.0 \mathrm{~m}^{3} \mathrm{ha}^{-1} \mathrm{yr}^{-1}$. However, $94.7 \%$ of the growth rate was attributed to the growth of the selected future crop trees alone (11.8\% of the trees). The relative participation of the future crop trees to the total overbark volume (V) of the stands increased by $66.3 \%$ (from 9.5 to $15.8 \%$ ). During the same period, the total overbark volume (V) from the thinning from below treatment increased from 432 in 1995 to $520 \mathrm{~m}^{3} \mathrm{ha}^{-1}$ in $2014(20.4 \%)$ at a mean growth rate of $4.6 \mathrm{~m}^{3} \mathrm{ha}^{-1} \mathrm{yr}^{-1}$. The total overbark volume $(\mathrm{V})$ of the unthinned stand decreased by $4.1 \%$, which was attributed to mortality in that period.

\section{Individual tree growth in dbh and basal area}

The current annual increments in dbh $\left(g_{\mathrm{dbh}}\right)$ and basal area $\left(g_{\mathrm{ba}}\right)$ ranged from 0.04 to $10.20 \mathrm{~mm}$ and from 0.12 to $43.8 \mathrm{~cm}^{2} \mathrm{yr}^{-1}$, respectively, during the time of the study (1977-2014, stand ages 52-89 yrs). Overall, the $g_{\text {dbh }}$ was similar before (1977-1995) and after (1995-2014) the treatments were applied for the unthinned $(1.85 \pm 0.99$, before; $1.82 \pm 1.03 \mathrm{~mm}$ $\mathrm{yr}^{-1}$, after), the thinning from below $(2.59 \pm 1.22$, before; $2.41 \pm 1.03 \mathrm{~mm} \mathrm{yr}^{-1}$, after), and the FCT thinning ( $2.58 \pm 1.34 \mathrm{~mm}$, before; $2.52 \pm 1.09 \mathrm{~mm}$ $\mathrm{yr}^{-1}$, after). For the basal area, the $g_{\mathrm{ba}}$ values were similar for the unthinned $(7.9 \pm 5.2$, before; $7.2 \pm$ $5.1 \mathrm{~cm}^{2} \mathrm{yr}^{-1}$, after) and the thinning from below 
(7.7 \pm 4.9 , before; $7.2 \pm 5.1 \mathrm{~cm}^{2} \mathrm{yr}^{-1}$, after) when comparing the period before and after 1995, while for the FCT, the $g_{\mathrm{ba}}$ values drastically increased from $7.8 \pm 4.6 \mathrm{~cm}^{2} \mathrm{yr}^{-1}$ before 1995 to $10.1 \pm 6.4$ $\mathrm{cm}^{2} \mathrm{yr}^{-1}$ after 1995 .

The future crop trees from the FCT-thinning after 1995 exhibited the greatest $g_{\text {dbh }}$ compared to the influenced and non-influenced trees of the FCT, the trees from the thinning from below and the control, in that order. The effect of the FCT thinning treatment on the $g_{\mathrm{dbh}}$ exceeded the growth response in both magnitude and length compared to the thinning from below. Visually, the effect of the FCT thinning treatment lasted for approximately 10 to $11 \mathrm{yrs}$, with an average diameter growth for that period of $3.85 \mathrm{~mm} \mathrm{yr}^{-1}$, compared to the growth before $\left(2.34 \mathrm{~mm} \mathrm{yr}^{-1}\right)$ and after $(2.01$ $\mathrm{mm}^{-1} \mathrm{r}^{-1}$ ) that period (Figure $2 \mathrm{a}$ ). In contrast, the effect of the thinning from below lasted for approximately 4 yrs after the thinning in 1995 (in absolute terms, from 2.23 in 1995 to $2.31 \mathrm{~mm}$ $\mathrm{yr}^{-1}$ in 1999). The magnitude of the effect of the thinning from below was very modest. The trees in the control, the unthinned treatment, gradually decreased in diameter growth from 2.23 in 1995 to $1.36 \mathrm{~mm} \mathrm{yr}^{-1}$ in 2014, which was clearly associated with natural decline with age (Figure 2a). Visually, the tree growth in the basal area $\left(g_{\text {ba }}\right)$ did not seem to decrease with age (Figure $2 \mathrm{~b})$, although statistically it did, as shown in the next section.

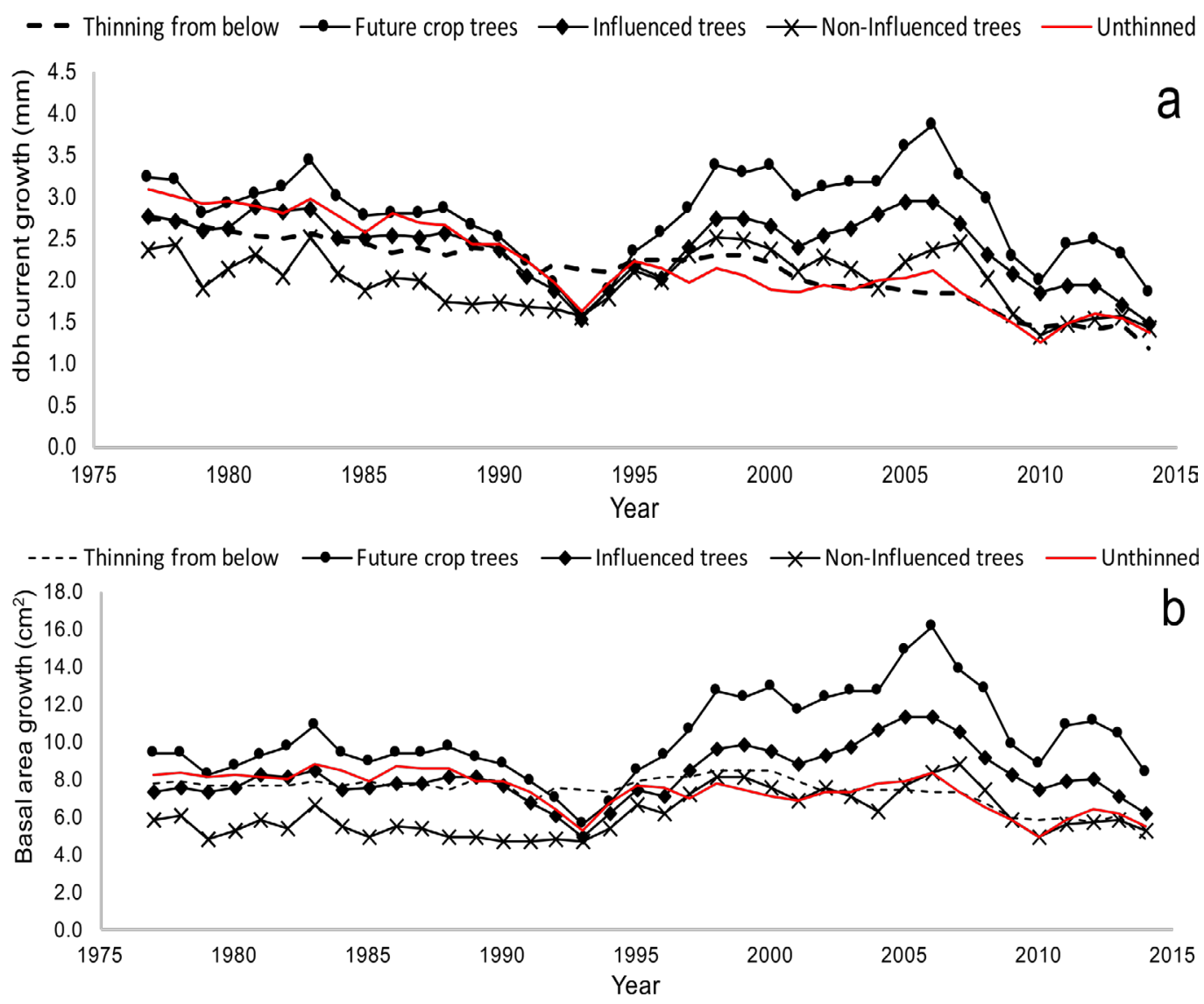

Figure 2. Current annual increment in (a) dbh and (b) tree basal area across thinning treatments. Values are the means for the future crop $(n=69)$ and the influenced $(n=34)$ and non-influenced trees $(n=20)$ within the FCT thinning, thinning from below $(\mathrm{n}=59)$ and control $(\mathrm{n}=52)$ trees. 


\section{Growth drivers of dbh and tree basal area}

The current annual increment in $\mathrm{dbh}\left(g_{\mathrm{dbh}}, \mathrm{mm}\right.$ yr $\left.{ }^{-1}\right)$ increased with $\mathrm{dbh}(\mathrm{cm})(\mathrm{P}<0.001)$ and absolute annual minimum temperature $\left({ }^{\circ} \mathrm{C}\right)(\mathrm{P}<0.001)$ and decreased with age $(\mathrm{yrs})(\mathrm{P}<0.001)$ (Table 2, Figure 3), i.e., $g_{\mathrm{dbh}}=6.277+0.029 \mathrm{dbh}-0.048$ age +0.026 Tmin. The same pattern was observed for the current annual increment in the tree basal area $\left(g_{\text {ba }}, \mathrm{cm}^{2} \mathrm{yr}^{-1}\right) ; g_{\text {ba }}=13.28+0.44 \mathrm{dbh}-0.15$ age +0.12 Tmin $(\mathrm{P}<0.001$ for all three variables $)$. Rainfall, air mean and maximum annual temperature did not influence the $g_{\mathrm{dbh}}$ or $g_{\text {ba }}$ values. The values of $g_{\mathrm{dbh}}$ would then increase by $0.029 \mathrm{~mm}$ for each additional $1 \mathrm{~cm}$ in $\mathrm{dbh}$, would decrease by $-0.048 \mathrm{~mm}$ for each additional $\mathrm{yr}$ of age and would increase by $0.026 \mathrm{~mm}$ for each additional $1^{\circ} \mathrm{C}$ increase in the absolute minimum annual temperature (Table 2). The directions of change of the $g_{\text {ba }}$ and $g_{\text {dbh }}$ values against the predictors were the same, i.e., values increased with dbh and annual absolute minimum temperature and decreased with age (Table 2).

\section{Discussion}

The thinning trial in this study lacks a robust experimental design, but it is probably one of the few studies on second-growth $N$. pumilio forests in Patagonia, monitored for $19 \mathrm{yrs}$ after the treatments were applied. Therefore, we do not attempt to extrapolate these results to the region and do not expect the reader to do so without a warning.
However, the unique character of this case study allows us to infer the overall growth responses of this forest to an FCT thinning and a thinning from below. These results may inform silviculturalists, forest ecologists and forest managers about the outcomes, although uncertain, about the advantages of using FCT for sustainable forest management of the second-growth forests of $N$. pumilio in Patagonia.

The slight growth increase in dbh and basal area of the residual trees after the thinning from below was applied is likely due to the low intensity of the first thinning ( $16.4 \%$ in the basal area, $\mathrm{G})$ and the lack of successive thinnings for the last $20 \mathrm{yrs}$ that led to excessive crown competition among the dominant and codominant trees. Several thinning trials in $N$. pumilio forests of low intensity have shown a small growth response (Schmidt et al., 2003). A thinning severity of $7.9 \%$ in the basal area $\left(1,167 \mathrm{~N} \mathrm{ha}^{-1} ; 76.4 \mathrm{~m}^{2} \mathrm{ha}^{-1} \mathrm{G}\right)$ exhibited a null increase in mean dbh growth after four yrs, and a severity of $21.1 \%$ in the basal area $(1,056 \mathrm{~N}$ ha $^{-1} ; 71.1 \mathrm{~m}^{2} \mathrm{ha}^{-1} \mathrm{G}$ ) showed an increase of $26.6 \%$ (from 1.5 to $1.9 \mathrm{~mm} \mathrm{yr}^{-1}$ ) in mean dbh growth after three yrs (Schmidt et al., 2003). The results from a thinning from below in a 100 -yr-old $N$. pumilio stand showed that the dbh growth after 20 yrs was $2.0 \mathrm{~mm} \mathrm{yr}^{-1}$ for the unthinned treatment $\left(1,317 \mathrm{~N} \mathrm{ha}^{-1} ; 24.7 \mathrm{~m}^{2} \mathrm{ha}^{-1} \mathrm{G}\right)$ compared to $4.9 \mathrm{~mm} \mathrm{yr}^{-1}$ when $\mathrm{G}$ was reduced by $74 \%(400 \mathrm{~N}$ $\left.\mathrm{ha}^{-1} ; 6.4 \mathrm{~m}^{2} \mathrm{ha}^{-1} \mathrm{G}\right)$ without considering the wood quality of the residual trees and the stability of the stand (Schmidt et al., 2003). This reinforces

Table 2. Current annual increment in $\mathrm{dbh}$ and basal area as explained by dbh, age and absolute minimum annual temperature for Nothofagus pumilio secondary forests. Only records from the unthinned stand were considered. Only significant variables were kept in the model.

\begin{tabular}{|c|c|c|c|c|}
\hline \multirow{3}{*}{ Variable } & \multicolumn{4}{|c|}{ Current annual increment } \\
\hline & \multicolumn{2}{|c|}{$\mathrm{dbh}(\mathrm{mm}$ yr -1) } & \multicolumn{2}{|c|}{ basal area $\left(\mathrm{cm}^{2} \mathrm{yr}-1\right)$} \\
\hline & Coefficient & P-value & Coefficient & P-value \\
\hline (Intercept) & 6.1895 & $<0.001 * * *$ & 12.8949 & $<0.001 * * *$ \\
\hline $\mathrm{dbh}$ & 0.0671 & $<0.001 * * *$ & 0.5812 & $<0.001 * * *$ \\
\hline Age & -0.0561 & $<0.001 * * *$ & -0.1795 & $<0.001 * * *$ \\
\hline $\mathrm{T}^{\mathrm{o}} \min$ & 0.0251 & $<0.001 * * *$ & 0.1184 & $<0.001 * * *$ \\
\hline
\end{tabular}



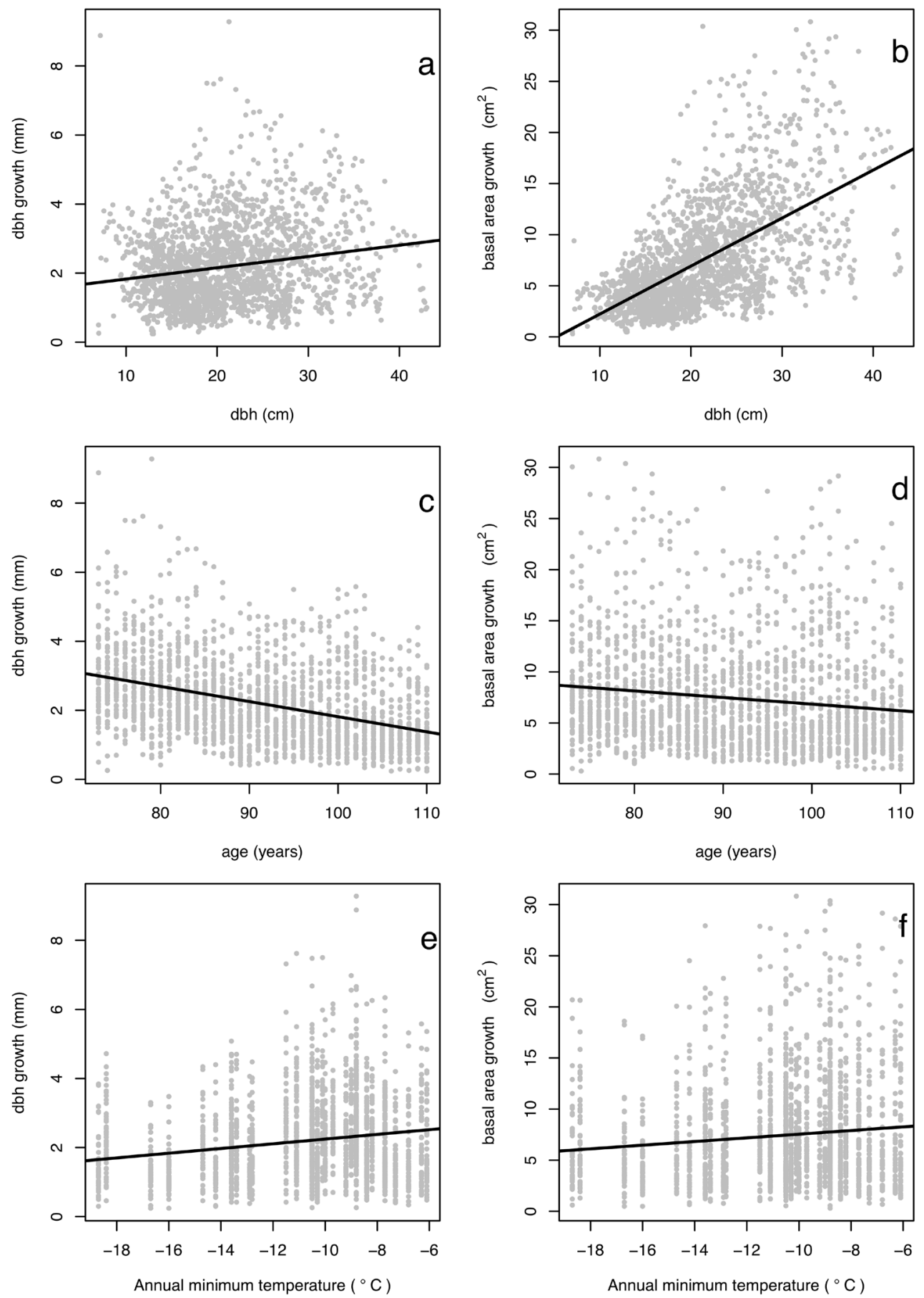

Figure 3. Significant relationships between the current annual increment in dbh (left panel) and basal area (right panel) and the dbh $(\mathrm{a}, \mathrm{b})$, age $(\mathrm{c}, \mathrm{d})$ and the absolute annual minimum temperature $\left({ }^{\circ} \mathrm{C}\right)(\mathrm{e}, \mathrm{f})$ for the unthinned control treatment. 
the idea that the thinning from below should be more severe and periodic to increase the growth of the thinned trees and maintain the productive capacity of the site.

In this study, future crop trees within the FCTthinning exhibited a mean current annual increment in dbh of $3.16 \pm 1.18 \mathrm{~mm} \mathrm{yr}^{-1}$ (58.8\% higher than the control trees) between 1995 and 2005 (Figure 4). Contreras (2004) found that for the 5 yrs following the FCT for the same trial reported in this study, there was a current dbh increment of $3.9 \mathrm{~mm} \mathrm{yr}^{-1}$, which is approximately $24 \%$ greater than dbh increment observed for the FCT after ten yrs. Therefore, we may speculate that a periodic release every 10 yrs would be needed to maintain the growth potential of the future crop trees.

Maulen (2015) found slow growth of selected trees under low intensity selective thinning. In a $50 \mathrm{yr}$ old $N$. pumilio secondary forest $\left(15,401 \mathrm{Nha}^{-1} ; 63\right.$ $\left.\mathrm{m}^{2} \mathrm{ha}^{-1} \mathrm{G}\right)$, they found a nonsignificant increase in $\mathrm{dbh}$ of $4.5 \%$ (from $2.2 \mathrm{~mm} \mathrm{yr}^{-1}$ before to $2.3 \mathrm{~mm}$ $\mathrm{yr}^{-1}$ after thinning) when the 606 young selected trees were released from their direct competitors. Peri et al. (2013) found that removing one, two and three or more competitors around each selected tree in a 40-yr-old secondary $N$. pumilio forest in Tierra del Fuego, Argentina, increased the dbh growth rate by $6.3 \%, 31.3 \%$ and $37.5 \%$, respectively, when compared to the control following the 10 yrs after thinning. Our mean annual increment in dbh (58.8\%) was greater than that observed by Maulen (2015) (4.5\%) and Peri et al. (2013) $(<38.0 \%)$ compared to the unthinned control treatment. In contrast, our dbh increments were smaller than those reported by Schmidt et al. (2003), where dbh growth was $63.6 \%$ and $68.2 \%$ greater when removing one or two competitors, respectively, from a $30 \mathrm{yr}$ old stand in Magallanes (compared to a control over $10 \mathrm{yrs}$ ). This would indicate a greater thinning growth response in younger trees after future crop tree release. However, $N$. pumilio trees as young as $30 \mathrm{yrs}$ old may have not yet differentiated their crowns, rendering them unfeasible for carrying out an FCT.

Future crop tree thinning caused significant changes in the forest structure during the 19-yr thinning trial. One of the major changes in the thinned plots, compared to the thinning from below and the control plots, was the concentration of the stand mortality on the influenced and non-influenced trees (99.3\%), which showed a

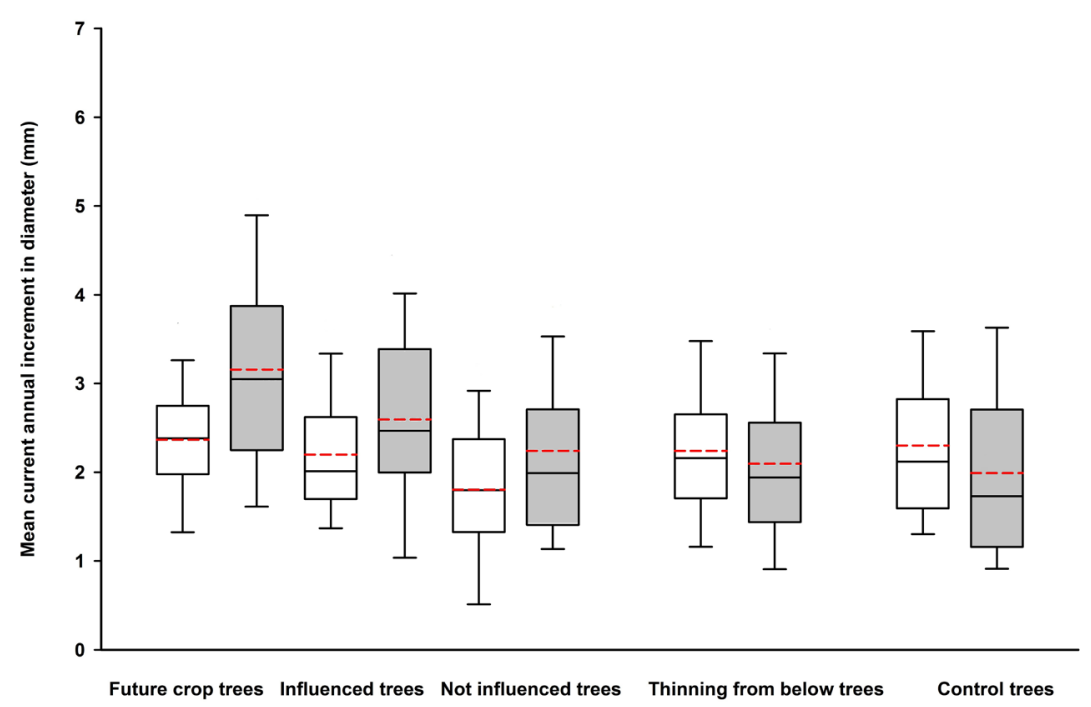

Figure 4. Mean current annual increment in diameter before (1985-1995; left box) and after (1996-2005; right box) thinning treatments were applied. The thinning treatments were FCT thinning (future crop tree, influenced and noninfluenced trees), thinning from below and the control. The central black line in the boxes represents the median, while the red dashed lines represent the mean annual increment in dbh. 
mortality rate $51.5 \%$ and $60.0 \%$ higher than that for the thinning from below trees and the control trees, respectively. In contrast, the mortality rate of the future crop trees was very low $(0.7 \%)$, and the diameter growth increased drastically over the 19-yr period after the FCT. The strict selection of a small number of future crop trees meeting the recommended criteria of vitality, quality and distance (Abetz, 1979) likely limited the mortality and maintained an adequate number of future crop trees. The above contrasts with the idea of selecting a large number of elite trees (or candidates to be final crop trees) and gradually selecting a smaller number of the best trees at each thinning cycle according to the traditional selective thinning method (Schädelin, 1942). This has been frequently controversial because FCT- thinning is commonly associated with considerable uncertainty and the risk of a negative change in the quality of the future crop trees due to this early and strict selection mechanism (Abetz, 1989). Despite the initial high quality of the future crop trees being selected, they could reverse their quality due to an insufficient thinning growth response (Milinsek et al., 1992, Maulen, 2015), damage caused by windthrow (Peri et al., 2013) or mechanical damage caused by felling and logging during the thinning cycles (Cruz,2017).

In an oak stand (Quercus robur L.) in Opočno, Czech Republic, it was shown that the selection of candidates and target trees at the small pole stage is a premature and risky decision (Chroust, 2007). They concluded that in a traditional selective thinning with an early selection of individuals, it is advisable to focus only on the vital and straight trees or to implement a selective thinning variant (sensu Abetz, 1979) in the form of future crop trees. Furthermore, Boncina et al. (2007) determined that in beech forest (Fagus sylvatica L.) in southeastern Slovenia, selective thinning was not beneficial to all the selected trees when too many crop trees were selected relative to the thinning intensity.

The alternative of selecting a greater number of future crop trees to ensure their quantity in the final stand to be harvested is not advised, since in no case would it lead to a decrease in the incidence of damage to future trees. The selection of the best trees in the course of stand development requires much more experience than a one-time determination and marking of the future crop trees that are to be promoted (Abetz, 1979). We propose that thinning protocols in secondary $N$. pumilio forests should consider a careful identification of a set of future crop trees, assuming that such a set would not appreciably change qualitatively over time.

The only environmental variable significantly explaining the annual growth rate in dbh and the basal area for the site was the absolute minimum annual temperature. For each $1^{\circ} \mathrm{C}$ increase in the annual absolute minimum temperature, the growth rate in dbh would increase by $0.025 \mathrm{~mm}$ $\mathrm{yr}^{-1}$, while the growth in the tree basal area would increase by $0.12 \mathrm{~cm}^{2} \mathrm{yr}^{-1}$. Aravena et al. (2002) analyzed 21 tree ring width chronologies of $N$. pumilio distributed between latitudes $51-55^{\circ} \mathrm{S}$ in Chile and found that tree growth positively correlated with the minimum annual air temperatures, and they used the correlation to reconstruct the climate of the time series. In contrast, Álvarez et al. (2015) found that the radial growth of $N$. pumilio was negatively correlated with precipitation in late spring (November-December) and positively correlated with air temperature in late spring and early summer (November-January) in humid high-elevation environments. Similarly, Norton (1984) found that tree growth was strongly related to air temperature during the austral summer months (December to March) for Nothofagus menziesi and N. solandri trees in the South Island of New Zealand. Ledgard and Norton (1988) similarly found that air temperature but not rainfall was positively correlated with the rate of shoot growth of seedlings of three New Zealand Nothofagus. Suarez et al. (2015) studied the ring chronosequences of Nothofagus dombeyi along a west-east precipitation gradient in Nahuel Huapi National Park, Argentina, showing that the critical factor regulating tree growth is a spring-summer 
water deficit brought about by above-average temperatures and reduced precipitation during the growing season. At high elevations, however, tree growth was less sensitive to water deficit but comparatively more sensitive to air temperature increases. Rubino and McCarthy (2000) found that the ring widths and basal area growth of Quercus alba $\mathrm{L}$. from an old-growth forest in southeastern Ohio, USA, correlated well with growing season (April-July) precipitation and drought severity. Therefore, interpreting the above, dbh growth will be limited by either water or temperature. In the case of the $N$. pumilio forest under study, water seems to be less limiting than temperature, and therefore, dbh growth would scale with air temperature. We may speculate that for yrs in which the absolute minimum annual temperature is much lower, the growing season might be shorter and colder, limiting $N$. pumilio development. In contrast, when the absolute minimum annual temperature is higher, the yrs may be expected to be warmer with a longer spring-summer growing season.
In summary, future crop tree thinning (in the sense of Z-Bäumen thinning) seems to be a better option for the management of secondgrowth N. pumilio forests in Southern Patagonia compared to thinning from below. The growth response of the FCT thinning was greater, lasted for a longer period (10 yrs) and involved less intensive silviculture than the thinning from below (4 yrs). The annual dbh and tree basal area growth was observed to increase with $\mathrm{dbh}$ and absolute minimum temperature and decrease with age across the studied range (90-110 yrs old).

\section{Acknowledgements}

The authors would like to thank CONAF through research project FIBN 016/2014. We are also grateful to Forestal Russfin Ltda. for the support and logistics for the establishment and maintenance of the thinning trial described in this study.

\section{Resumen}

G.E. Cruz, F.A. Rodríguez, P.A. Tapia y H.E. Bown. 2018. Respuestas en crecimiento después de un raleo con árboles futuro y un raleo por lo bajo en un bosque secundario de Nothofagus pumilio, en Tierra del Fuego, Chile. Cien. Inv. Agr. 45(3): 263-276. Nothofagus pumilio (lenga) es la especie nativa más importante para la producción maderera del sur de la Patagonia (Chile y Argentina). Raleos en bosques secundarios de N. pumilio no han sido de interés probablemente debido al largo tiempo de recuperación de la inversión. Además, mayoritariamente se han ensayado raleo por lo bajo, dejando un rodal residual denso y con bajo crecimiento diamétrico. Usando mediciones (1995-2014) de un ensayo de raleo instalado en 1995 en un bosque secundario de N. pumilio, en Tierra del Fuego (Chile), el objetivo de este estudio de caso fue analizar, si raleos selectivos con árboles futuro (en el sentido de Z-Bäumen), originan un mayor crecimiento diamétrico que un raleo por lo bajo. Además, se exploran asociaciones entre factores climáticos y la edad en el crecimiento diametral de N. pumilio, para interpretar los efectos del raleo en los bosques. Los ensayos consistieron en un testigo, un raleo por lo bajo y un raleo selectivo con árboles futuro. La respuesta en crecimiento diametral del raleo selectivo con árboles futuro fue mayor y se prolongó por más tiempo (10 años), respecto del raleo por lo bajo (4 años). El crecimiento diamétrico y en área basal para el testigo se incrementó con el diámetro y la temperatura mínima absoluta y disminuyó con la edad a lo largo del período 1977-2014 ( 70-110 años de edad). El raleo selectivo con árboles futuro representaría una mejor opción para el manejo de los bosques secundarios de N. pumilio, respecto del raleo por lo bajo.

Palabras clave: Factores climáticos, lenga, métodos de raleo, Patagonia. 


\section{References}

Abetz, P. 1979. Beitrage zur Bestandesplege. Zukunftsbäume und Baumzahlhaltung Allgemeine Forstzeitschrift 90:287-291.

Abetz, P. 1989. Zu den Ursachen des "Umsetzens" von (Z-) Bäumen. Allgemeine Forst Zeitschrift 44:1334-1337.

Álvarez, C., T.T. Veblen, D. Christie, and Á. González-Reyes. 2015. Relationships between climate variability and radial growth of Nothofagus pumilio near altitudinal treeline in the Andes of northern Patagonia, Chile. Forest Ecology and Management 342:112-121.

Aravena, J. C., A. Lara, A. Wolodarsky-Franke, R. Villalba, and E. Cuq. 2002. Tree-ring growth patterns and temperature reconstruction from Nothofagus pumilio (Fagaceae) forests at the upper tree line of southern Chilean Patagonia. Revista Chilena de Historia Natural. 75(2):361-376.

Boncina, A., A. Kadunc, and D. Robic. 2007. Effects of selective thinning on growth and development of beech (Fagus sylvatica L.) forest stands in south-eastern Slovenia. Ann. For. Sci. 64:47-57.

Caldentey, J. 1995. Acumulación de biomasa en rodales naturales de (Nothofagus pumilio (Poepp. et Endl.) Krasser) en Tierra del Fuego, Chile. Forest System, 4(2):166-175.

Chávez, R. 2002. Rendimiento de trozas y crecimiento en un renoval raleado de lenga (Nothofagus pumilio (Poepp. et Endl.) Krasser), en Tierra del Fuego, XII Región. Universidad de Chile, Escuela de Ciencias Forestales. Santiago, Chile. Memoria Ing. Forestal. 34 p.

Chroust, L. 2007. Quality selection in young oak stands. Journal of Forest Science 53(5):210-221.

Contreras, C. 2004. Evaluación del efecto de un raleo selectivo sobre el crecimiento en un renoval de Nothofagus pumilio (Poepp. et Endl.) Krasser, en Tierra del Fuego, XII Región. Universidad de Chile, Escuela de Ciencias Forestales. Santiago, Chile. Memoria Ing. Forestal. 49 p.

Corporación Nacional Forestal (CONAF) 2011. Catastro de los recursos vegetacionales nativos de Chile, Monitoreo de Cambios y Actualizaciones. Período 1997-2011. Lom Ediciones Ltda. Santiago, Chile. 87 p.

Cruz, G. 2017. Raleos selectivos de árboles futuro en renovales de Nothofagus pumilio, como alternativa para fortalecer la aplicación de los incentivos contenidos en la Ley 20.283. Informe Final. Proyecto 016/2014. Fondo de Investigación de Bosque Nativo CONAF. Santiago 45 p.

Cruz, G. and, H. Schmidt. 2007. Silvicultura de Bosque Nativo. En: De la Maza, C., Hernandez, J. and Estades, C. 2007. Biodiversidad: Manejo y conservación de los recursos forestales. Universidad de Chile, Facultad de Ciencias Forestales. Editorial Universitaria. Santiago. 279-307.

Gajardo, R. 1994. La vegetación natural de Chile. Clasificación y distribución geográfica. Editorial Universitaria. $165 \mathrm{p}$.

Helms, J.A., ed. 1998. The dictionary of forestry. Bethesda, MD: Society of American Foresters. 210p.

Lara, A., and G. Cruz. 1987. Vegetación del área de uso agropecuario de la XII Región, Magallanes y de la Antártica Chilena. Instituto de Investigaciones Agropecuarias (INIA), Intendencia de la XII Región, Magallanes y Antártica Chilena. Santiago. 23 p.

Ledgard, N. J., and D. Norton. 1988. Shoot growth in 2-3-yr-old Nothofagus seedlings. New Zealand Journal of Ecology.

Maulen, F. 2015. Efecto de un raleo selectivo sobre el crecimiento de árboles en un renoval de lenga (Nothofagus pumilio (Poepp. Et Endl.) Krasser) en el predio Monte Alto, XII Región de Magallanes y de la Antártica chilena. Universidad de Chile, Facultad de Ciencias Forestales y la Conservación de la Naturaleza. Santiago, Chile. Memoria Ing. Forestal 24 p.

Neira, E. and E. Rivas. 2013. Evaluación del fondo de conservación, recuperación y manejo sustentable del bosque nativo (ley 20.283). Revista Bosque Nativo 52:26-28.

Nyland, R. 2016. Silviculture: Concepts and Applications, Third Edition. Waveland Press, Inc. Long Grove, Illinois 680 pp. 
Norton, D. a. 1984. Tree-growth-climate relationships in subalpine Nothofagus forests, South Island, New Zealand. New Zealand Journal of Botany, 22(February), 471-481.

Peri, P., G. Martínez Pastur, R. Vukasovic, B. Díaz, M. Lencinas, and J. Cellini. 2002. Thinning schedules to reduce risk of windthrow in Nothofagus pumilio forests of Patagonia, Argentina. Bosque 23(2):19-28.

Peri, P., G. Martínez Pastur, and L. Monelos. 2013. Natural dynamics and thinning response of young lenga (Nothofagus pumilio) trees in secondary forests of Southern Patagonia. Bosque 34(3):273-279.

Pretzsch, H. 2009. Forest Dynamics, Growth and Yield from Measurement to Model. Springer. Berlín, Alemania. 664 p.

R Core Team, 2013. R: A language and environment for statistical computing. R Foundation for Statistical Computing, Vienna, Austria. URL http:// www.R-project.org/.

Rebertus, A.J., T. Kitzberger, T.T. Veblen, and L.M. Roovers. 1997. Blowdown history and landscape patterns in the Andes of Tierra del Fuego, Argentina. Ecology 78:678-692.

Rubino, D. L., and B.C. McCarthy. 2000. Dendroclimatological analysis of white oak (Quercus alba L., Fagaceae) from an old-growth forest of southeastern Ohio, USA. Journal of the Torrey Botanical Society 127(3):240-250.
Schädelin W. 1942.Die Ausleseduchforstung als Erziehungsbetrieb höchster Wertleistung. 3. Auflage. Bern, Leipzig, Verlag P. Haupt: $115 \mathrm{~s}$.

Schmidt, H., and A. Urzúa. 1982. Transformación y manejo de los bosques de lenga en Magallanes. Facultad de Ciencias Agrarias, Veterinarias y Forestales. Universidad de Chile. Santiago, Chile. Ciencias Agrícolas No 11.62 p.

Schmidt, H., G. Cruz, A. Promis, and M. Álvarez. 2003. Transformación de los bosques de lenga vírgenes e intervenidos a bosques manejados. Guía para los bosques demostrativos. Publicaciones Misceláneas Forestales No 4, Facultad de Ciencias Forestales, Universidad de Chile. 60 p.

Stokes, M.A., and T.L. Smiley. 1996. An introduction to tree-ring dating. The University of Arizona Press. Tucson, Arizona $73 \mathrm{p}$.

Suarez, M. L., R. Villalba, I.A. Mundo, and N. Schroeder. 2015. Sensitivity of Nothofagus dombeyi tree growth to climate changes along a precipitation gradient in northern Patagonia, Argentina. Trees, 29(4):1053-1067.

Tuhkanen, S. 1992. The climate of Tierra del Fuego from vegetation geographical point of view and its ecoclimatic counterparts elsewhere. Ann. Bot. Fenn. 145:1-64.

Uriarte, A., and H. Grosse. 1991. Los bosques de lenga (Nothofagus pumilio (Poepp. et Endl.) Krasser). Una orientación para su manejo (recopilación bibliográfica). Instituto Forestal. Informe técnico 126. Concepción, Chile. 119 p. 